\section{BIOSYNTHESIS OF ANTIBIOTIC A23187 INCORPORATION OF PRECURSORS INTO A23187}

NOTE

\section{MiLton J. ZMiJewsKI, Jr.}

Department of Medicinal Chemistry, College of Pharmacy, University of Utah, Salt Lake City, Utah 84112, U.S.A.

(Received for publication February 2, 1980)

Streptomyces chartreusis NRRL 3881 produces the divalent cation ionophore antibiotic A23187 ${ }^{1}$. This antibiotic is primarily active against Grampositive bacteria and fungi and has been used extensively to investigate the role of divalent cations in regulating cellular physiological processes $^{2,3,4)}$. The chemical structure of A23187 $7^{5,6}$ ) indicates that it is a member of a new class of ionophorous antibiotics, the pyrrole polyethers. ${ }^{7)}$ The only other antibiotic in this class is the recently discovered $\mathrm{X}-14547 \mathrm{~A}^{8)}$. In this report, the incorporation and labeling pattern of ${ }^{14} \mathrm{C}$ and ${ }^{13} \mathrm{C}$-labeled precursors into $\mathrm{A} 23187$ is described.

Antibiotic A23187 (1a) is a mono-carboxylic acid consisting of three structural units; an $\alpha$ ketopyrrole, a substituted benzoxazole and a spiroketal ring $^{5)}$. The $\alpha$-ketopyrrole moiety could arise from proline or acetate while the

Table 1. Incorporation of ${ }^{14} \mathrm{C}$-labeled substrates into A23187 methylester.

\begin{tabular}{l|c}
\hline Substrate (sodium salt) & \% Incorporation \\
\hline Propionate-3-3- $\mathrm{C}$ & 28.4 \\
Propionate-2- ${ }^{14} \mathrm{C}$ & 18.0 \\
Propionate-1- ${ }^{14} \mathrm{C}$ & 8.1 \\
Acetate-2- ${ }^{14} \mathrm{C}$ & 1.6 \\
Acetate-1- ${ }^{14} \mathrm{C}$ & 1.8 \\
L-Proline-U- ${ }^{14} \mathrm{C}$ & 24.2 \\
D,L-Ornithine-1- ${ }^{14} \mathrm{C}$ & 0.55 \\
D-Glucose-U- ${ }^{14} \mathrm{C}$ & 1.3 \\
Glycerol-U-U- $\mathrm{C}$ & 0.5 \\
D,L-Tryptophan-7a- ${ }^{14} \mathrm{C}$ & 0 \\
L-Methionine-5- $-{ }^{14} \mathrm{CH}_{3}$ & 22.0 \\
\hline
\end{tabular}

spiroketal ring system could be formed by propionate and acetate ${ }^{9)}$ or by condensation of acetate units with $\mathrm{C}$-methyl groups arising through transmethylation from a $\mathrm{C}_{1}$-donor ${ }^{10)}$. The aromatic ring of the benzoxazole moiety could be derived from 3-hydroxyanthranilic acid via tryptophan $^{11)}$ or from glucose metabolism via a shikimic type intermediate ${ }^{12}$. These possibilities were tested by determining the incorporation of ${ }^{14} \mathrm{C}$-labeled precursors into the antibiotic (Table 1).

Radioisotope labeled substrate $(\sim 10 \mu \mathrm{Ci}$ to $50 \mu \mathrm{Ci} / 50 \mathrm{ml}$ culture broth) were added to individual cultures of $S$. chartreusis three days after inoculation. Cultures were harvested twentyfour hours later and A23187 was isolated, converted to its acid form, methylated with diazomethane, and purified by chromatography as described elsewhere ${ }^{1)}$.

The results (Table 1) indicated that methionine, propionate, acetate, glycerol, glucose, proline and ornithine were all efficiently incorporated into A23187 methylester (1b). Information on the labeling pattern of these precursors was obtained by chemical degradation of the specifically radioisotope labeled antibiotic (Table 2).

KuHN-Rотн oxidation ${ }^{13)}$ of the antibiotic made possible the isolation of carbons $19^{\prime}$ and $19,17^{\prime}$ and $17,15^{\prime}$ and 15 , and $11^{\prime}$ and 11 in the form of sodium acetate. ScHMid degradation ${ }^{13)}$ of the sodium acetate derived from the K-R oxidation yields monomethyl amine and $\mathrm{CO}_{2}$ from $\mathrm{C}-2$ and $\mathrm{C}-1$ of the acetate, respectively. The results (Table 2) indicate that the $\mathrm{C}-3$ and $\mathrm{C}-2$ of propionate are the source of the methyl and adjacent methylenes of the spiroketal ring of A23187. The specific activity of the sodium acetate derived from A23187 labeled from propionate $\left[3-{ }^{14} \mathrm{C}\right]$ and $\left[2-{ }^{14} \mathrm{C}\right]$ is one quarter that of the labeled antibiotic.

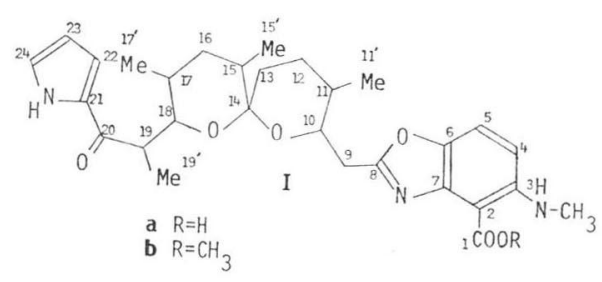


Table 2. Degradation of specifically labeled A23187 methylesters.

\begin{tabular}{|c|c|c|c|c|c|}
\hline \multirow[t]{2}{*}{ Precursor } & \multirow{2}{*}{$\begin{array}{c}\text { Spec. act. } \\
\left(\times 10^{2}\right) \text { of } \\
\text { A23187 ME } \\
(\mu \mathrm{Ci} / \mu \text { mole })\end{array}$} & \multirow{2}{*}{$\begin{array}{l}\text { Spec. act. of } \\
\text { sodium ace- } \\
\text { tate from } \\
\mathrm{KRO} \times 10^{2} \\
(\mu \mathrm{Ci} / \mu \text { mole })\end{array}$} & \multicolumn{2}{|c|}{$\begin{array}{l}\text { SCHMIDT degradation } \\
\% \text { of recovered } \\
\text { radioactivity in }\end{array}$} & \multirow{2}{*}{$\begin{array}{l}\% \text { of Total } \\
\text { precursor label } \\
\text { found in } \\
\text { sodium acetate }\end{array}$} \\
\hline & & & $\mathrm{CH}_{3} \mathrm{NH}_{2}$ & $\mathrm{CO}_{2}$ & \\
\hline Propionate- $3-{ }^{14} \mathrm{C}$ & 3.0 & 0.78 & 95.3 & 4.7 & 100 \\
\hline Propionate- $2-{ }^{14} \mathrm{C}$ & 2.4 & 0.54 & 5.8 & 94.2 & 100 \\
\hline Propionate- $1-{ }^{14} \mathrm{C}$ & 1.6 & 0 & N.D. & N.D. & - \\
\hline Acetate- $2-{ }^{14} \mathrm{C}$ & 1.9 & 0.064 & 56 & 44 & 30 \\
\hline Acetate $-1-{ }^{14} \mathrm{C}$ & 1.2 & 0.060 & 22 & 88 & 10 \\
\hline Methionine $\left(\mathrm{S}-{ }^{14} \mathrm{CH}_{3}\right)$ & 1.1 & 0 & N.D. & N.D. & - \\
\hline Glucose $\left(\mathrm{U}-{ }^{14} \mathrm{C}\right)$ & 0.61 & 0 & N.D. & N.D. & 10 \\
\hline
\end{tabular}

KRO; K-R oxidation. N.D.; Not determined.

This is consistent with the idea that all four of the methyl group and adjacent methylenes of the spiroketal ring are derived from $\mathrm{C}-3$ and $\mathrm{C}-2$ of propionate, respectively. The results of the SCHMid degradation of the $\left[3-{ }^{14} \mathrm{C}\right]$ and $\left[2-{ }^{14} \mathrm{C}\right]$ propionate labeled acetates are also consistent with this proposal. The finding that $100 \%$ of the label that $\left[3-{ }^{14} \mathrm{C}\right]$ and $\left[2-{ }^{14} \mathrm{C}\right]$ propionate contribute to the antibiotic molecule is found at these carbons indicates that propionate is a direct precursor and not metabolically transformed prior to incorporation. The sodium acetate derived from the K-R oxidation of $\left[2-{ }^{14} \mathrm{C}\right]$ and $\left[1-{ }^{14} \mathrm{C}\right]$ acetate labeled A23187 methylester was also found to be labeled but the results are consistent with the metabolic conversion of acetate to propionate prior to its incorporation. Other attempts to degrade the antibiotic proved fruitless and so in order to examine the role of proline and methionine in the biosynthesis of $\mathrm{A} 23187,{ }^{18} \mathrm{C}$ labeled precursors in conjunction with ${ }^{13} \mathrm{C}-\mathrm{NMR}$ was used (Table 3).

Comparison of the FT-proton noise decoupled ${ }^{13} \mathrm{C}$-NMR natural abundance spectrum with that of the D,L-proline- $1-{ }^{13} \mathrm{C}$ enriched antibiotic (Table 3) demonstrated a 7-fold enrichment of the peak at $194.3 \mathrm{ppm}$ which had been assigned previous$1 y^{14)}$ to C-20 (the $\alpha$-keto carbon of the $\alpha$-ketopyrrole moiety). The spectrum of methionine $\left(\mathrm{S}^{13} \mathrm{CH}_{3}\right)$ enriched A23187 methylester also showed only one enriched signal (30.3 ppm) assigned to the $\mathrm{N}$-methyl group of the benzoxazole moiety.

The origin of the substituted aromatic ring of the benzoxazole moiety remains to be determined. Tryptophan-7a $-{ }^{14} \mathrm{C}$ was not incorporated into the antibiotic indicating that its degradation pro- duct, 3-hydroxyanthranilic acid, is not a precursor for this part of the molecule. The finding that glucose-U- ${ }^{14} \mathrm{C}$ labels the antibiotic but poorly labeled the carbons derived from KuHN-RoTH oxidation (Table 2), suggests that this part of the antibiotic may be derived from a shikimate type intermediate as has been suggested for the aromatic functionalities found in the streptovaricins $^{15)}$, mitomycins ${ }^{16)}$, geldanamycin ${ }^{15)}$, rifa$\operatorname{mycin}^{12)}$ and pactamycin ${ }^{17)}$.

The results allow the following conclusions to be drawn: (1) the spiroketal ring of A23187 is derived from the condensation of propionate and possibly acetate as has been reported for the streptovaricins and rifamycins ${ }^{14)},(2)$ proline, probably via ornithine, is the precursor for the $\alpha$ ketopyrrole moiety and (3) methionine contributes only one carbon to the antibiotic at the C-3' position (N-methyl). Additional studies with ${ }^{13} \mathrm{C}$-labeled precursors are underway to determine more conclusively the role of acetate and propionate in forming the spiroketal ring, to establish the precursors for the benzoxazole moiety, and to demonstrate the role of ornithine in the biosynthesis of the $\alpha$-ketopyrrole moiety.

\section{Acknowledgments}

This work was supported by a grant from the University of Utah, College of Pharmacy, Ad Hoc Committee. Special thanks to Dr. R. Hamill of Eli Lilly for reference samples of A23187 and to Dr. L. H. HURLEY of the University of Kentucky for the C-13 labeled methionine. The technical assistance of JонN W. PIZ and DAVID WINGATE are also gratefully acknowledged. 
Table 3. Incorporation of $\mathrm{D}, \mathrm{L}-$ proline-1-19 $\mathrm{C}$ and $\mathrm{D}, \mathrm{L}-$ methionine- $\mathrm{CH}_{3}{ }^{13} \mathrm{C}$ into $\mathrm{A} 23187$ methylester as determined by ${ }^{13} \mathrm{C}-\mathrm{NMR} .{ }^{\mathrm{a}}$

\begin{tabular}{|c|c|c|c|c|}
\hline $\begin{array}{l}\text { Chemical shift } \\
\text { ppm (TMS) }\end{array}$ & $\begin{array}{c}\mathrm{D}, \mathrm{L}-\mathrm{Proline}-1-{ }^{13} \mathrm{C} \\
\text { enrichment } \times \text { natural } \\
\text { abundance }\end{array}$ & $\begin{array}{c}\mathrm{D}, \mathrm{L}-\mathrm{Methionine}-\mathrm{CH}_{3^{-13}} \mathrm{C} \\
\text { enrichment } \times \text { natural } \\
\text { abundance }\end{array}$ & Assignment & $\begin{array}{c}\text { Functional } \\
\text { group }\end{array}$ \\
\hline 194.3 & 7.0 & 0.6 & C-20 & \\
\hline 168.6 & 0.9 & 0.6 & C-1 & $-\mathrm{COOH}$ \\
\hline 165.9 & 0.7 & 0.6 & C-8 & \\
\hline 150.5 & 1.0 & 0.6 & & \\
\hline 142.2 & 0.9 & 0.5 & & \\
\hline 133.6 & 0.6 & 0.4 & C-3, C-6, C-7, & \\
\hline 123.6 & 0.9 & 0.5 & $\left\{\begin{array}{l}\mathrm{C}-21, \mathrm{C}-22, \\
\mathrm{C}-23, \mathrm{C}-24,\end{array}\right\}$ & \\
\hline 116.1 & 1.0 & 0.4 & $\mathrm{C}-4, \mathrm{C}-5$ & \\
\hline 109.8 & 0.9 & 0.7 & & \\
\hline 107.7 & 1.0 & 0.6 & & \\
\hline 100.4 & 0.7 & 0.4 & $\mathrm{C}-2$ & $\mathrm{COOH}$ \\
\hline 98.5 & 0.8 & 0.5 & C-14 & \\
\hline 73.8 & 0.9 & 1.0 & $\{C-10\}$ & $\mathrm{H}-\stackrel{\mathrm{C}}{\mathrm{C}}-\mathrm{O}$ \\
\hline 68.3 & 0.8 & 1.2 & {$[C-18]$} & $x+7$ \\
\hline 51.8 & 1.0 & 1.0 & $\mathrm{C}-1$ & $-\mathrm{COOCH}_{3}$ \\
\hline 42.7 & 0.9 & 1.0 & N.A. & \\
\hline 35.3 & 0.9 & 1.2 & N.A. & \\
\hline 32.5 & 1.4 & 1.1 & N.A. & \\
\hline 30.3 & 1.0 & 16.4 & C- $3^{\prime}$ & $\mathrm{N}-\mathrm{CH}_{3}$ \\
\hline 29.0 & 0.8 & 1.0 & N.A. & \\
\hline 28.4 & 0.9 & 1.1 & N.A. & \\
\hline 25.5 & 1.1 & 1.2 & N.A. & \\
\hline 16.1 & 1.0 & 1.4 & & \\
\hline 12.4 & 0.8 & 1.4 & $\mathrm{C}-11^{\prime}, \mathrm{C}-15^{\prime}$ & $-\stackrel{\mathrm{C}}{\mathrm{C}}-\mathrm{CH}_{3}$ \\
\hline 11.1 & 1.0 & 1.4 & $\mathrm{C}-1^{\prime}, \mathrm{C}-19^{\prime}$ & $-c 13_{3}$ \\
\hline 10.6 & 0.9 & 1.2 & & \\
\hline
\end{tabular}

a Proton decoupled ${ }^{13} \mathrm{C}-\mathrm{NMR}$ FT spectrum were recorded on a Varian XL-100 spectrometer at 25.2 MHz. N.A. Not Assigned.

\section{References}

1) Gale, R. M.; C. E. Higgens \& M. M. Hoehm: Antibiotic A23187 and process for preparation thereof.U.S. Patent No. 3,960,667. June 1, 1976

2) Garrison, J. C.: The effects of glucagon, catecholamines and the calcium ionophore A23187 on the phosphorylation of rat hepatocyte cytosolic proteins. J. Biol. Chem. 253: $7091 \sim$ 7100,1978

3) Mitani, M. \& N. Ōtake: Studies on the ionophorous antibiotics. XVI. The ionophoremediated calcium transport and concomitant osmotic swelling of mitochondria. J. Antibiotics 31: $888 \sim 893,1978$

4) Ashby, J. P. \& R. N. Speake: Insulin and glucagon secretion from isolated islets of LANGERHANS. Biochem. J. 150: 89 96, 1975
5) Chaney, M. O.; P. V. Demarco, N. D. Jones \& J. L. OcColowitz: The structure of A23187, a divalent cation ionophore. J. Amer. Chem. Soc. 96: 1932 1933, 1974

6) Chaney, M. O.; N. D. Jones \& M. Debono: The structure of the calcium complex of A23187, a divalent cation ionophore antibiotic. J. Antibiotics 29: 424 428, 1976

7) Westley, J. W.: Polyether antibiotics: Versatile carboxylic acid ionophores produced by Streptomyces. Adv. App. Microb. 22:177 221, 1977

8) Westley, J. W.; R. H. Evans, C. M. Liu, T. Herrmann \& J. F. Blount: Structure of antibiotic X-14547A, a carboxylic acid ionophore produced by Streptomyces antibioticus NRRL 8167. J. Amer. Chem. Soc. 100: 6784 6786, 1978 
9) Day, L. E.; J. W. Chamberlin, E. Z. Gordee, S. Chen, M. Gorman, R. L. Hamill, T. Ness, R. E. Weeks \& R. Stroshane: Biosynthesis of monensin. Antimicr. Agents \& Chemoth. 4: 410 414, 1973

10) LiU, C. M.; T. H. Williams \& R. G. Pitcher: ${ }^{13} \mathrm{C}$-NMR studies on the biosynthesis of aurodox. J. Antibiotics 32: 414 417, 1979

11) Hurley, L. H. \& C. Gairola: Pyrrolo $(1,4)$ benzodiazepine antitumor antibiotics; biosynthetic studies on the conversion of tryptophan to the anthranilic acid moieties of sibiromycin and tomaymycin. Antimicr. Agents \& Chemoth. 15: $42 \sim 45,1979$

12) White, R. J. \& E. Martinelli: Ansamycin biosynthesis: Incorporation of $\left[1-{ }^{13} \mathrm{C}\right]$ glucose and $\left[1-{ }^{13} \mathrm{C}\right]$ glycerate into the chromophore of rifamycin S. FEBS Letters 49: $233 \sim 236,1974$

13) Simon, H. \& H. G. Floss: Bestimmung der
Isotopen Verteiling in Markierten Verbindunzen. Springer-Verlag, West Berlin, 1967

14) Deber, C. J. \& D. R. PfeIfFer: Ionophore A23187. Solution conformations of the calcium complex and free acid deduced from proton and carbon-13 nuclear magnetic resonance studies. Biochemistry 15: 132 141, 1976

15) Rinehart, K. L., Jr. \& L. S. Shields: Chemistry of ansamycin antibiotics. Fortsch. Chem. Org. Natur. 33: 231, 1976

16) Hornemann, U.; J. P. Kehner \& J. H. Eggert: Pyruvic acid and D-glucose in mitomycin biosynthesis by Streptomyces verticillatus. J. Chem. Soc., Chem. Comm. 1974: 1045 1046, 1974

17) Weller, D. D. \& K. L. Rinehart, Jr.: Biosynthesis of the antitumor antibiotic pactamycin. A methionine-derived ethyl group and a $\mathrm{C}_{7} \mathrm{~N}$ unit. J. Amer. Chem. Soc. 100: 6757 6760, 1978 